\title{
PELAYANAN PASTORAL YANG MELIBATKAN TUBUH: INTEGRASI ANTARA KATA DAN TUBUH
}

\author{
Pauline Patricia \\ Sekolah Tinggi Filsafat Theologi Jakarta \\ uline.lagonda@gmail.com
}

\begin{abstract}
This paper proposes an integrated pastoral service model. I begin with a fundamental question, what kind of pastoral care is right for people who are traumatized? Pastoral care with the dimension of voice and words will certainly be very difficult for those who are unable to speak their wound experience. Because, trauma causes someone's memory and life to be fragmented, making it difficult for them to be open and tell stories. Therefore, integrated pastoral care between verbatim and psycho-physiotherapy can be an alternative for counselors dealing with those who have experienced trauma. This paper will begin with the reality of the wound that does not always allow anyone to speak verbally. Next, I will frame pastoral care which involves anesthetic-therapeutic dimension as an alternative. Finally, this paper will conclude with conclusions and reflections.
\end{abstract}

Keywords: healing; integration; pastoral care; trauma

\section{Pendahuluan}

Di dalam bukunya yang berjudul In an Unspoken Voice, Peter A. Levine mengatakan bahwa tubuh adalah storyteller. Tubuh mengatakan apa yang tidak terkatakan oleh kata. Sekalipun tubuh tidak berkata secara verbal tetapi tubuh bertutur melalui caranya yang khas. F. M. Alexander sebagaimana dikutip Levine mengatakan, "the body is the best picture of the mind" ${ }^{\prime \prime}$. Tubuh merefleksikan ingatan yang tersimpan dalam memori manusia. Namun, tidak banyak orang menyadari gejala ini, baik orang yang mengalami pengalaman traumatis maupun konselor.

Penulis akan memfokuskan tulisan ini pada pengalaman traumatis akibat kekerasan seksual yang dialami oleh perempuan. Sebagaimana dicatat dalam Catatan Tahunan (CATAHU) yang dikeluarkan oleh Komnas Perempuan, angka kekerasan seksual yang dialami oleh perempuan mengalami peningkatan setiap tahunnya. Artinya, perempuandan anak-masih dalam posisi yang tidak aman di Indonesia. Kenyataan tersebut harus menjadi perhatian gereja dan teologi untuk mempertimbangkan model pelayanan pastoral

${ }^{1}$ Peter A Levine, In an Unspoken Voice: How the Body Releases Trauma and Restores Goodness. (California: North Atlantic Books, 2010): 157. 
seperti apa yang harus dilakukan bagi para korban dan penyintas kekerasan seksual. Lebih dari itu, perempuan korban kekerasan seksual, pemerkosaan secara khusus, akan mengalami pengalaman traumatis yang terekam dalam ingatan dan tubuhnya. Pauline dalam tesisnya menuliskan bahwa,

Trauma akibat pemerkosaan yang dialami oleh perempuan menjadi sangat khas dan partikular karena menyangkut pemaknaan tubuh yang terdistorsi. Penderitaan perempuan akibat kekerasan mengendap dalam diri (tubuh) dan ingatan. Trauma menyebabkan ingatan dan kata terfragmentasi (terpecah belah, Ing.: rupture). Oleh karena itu, orang yang mengalami trauma acapkali tidak mampu menyuarakan narasi derita mereka dengan mudah ${ }^{2}$.

Bagi perempuan yang mengalami trauma akibat pemerkosaan, mulut terbungkam tidak mampu berkata, tidak tahu harus memulai kisahnya dari mana. Ingatan yang terfragmentasi membuat para penyintas gagap dalam membahasakan luka. Karena itu, pertanyaan yang menjadi dasar dalam pembahasan ini adalah bagaimanakah proses pemulihan - dalam hal ini melalui pelayanan pastoral-dapat dilakukan atas orang yang kesulitan dalam membahasakan pengalaman lukanya secara utuh? Bagaimanakah seharusnya seorang konselor menghadapi konseli yang minim kata dan bahasa saat pelayanan pastoral? Apakah suara dan kata merupakan satu-satunya tanda terjadinya pemulihan?

Tulisan ini akan dibatasi pada persoalan trauma dengan pelayanan pastoral yang dialami maupun dilakukan secara individual. Secara khusus atas mereka yang mengalami trauma akibat pelecehan seksual. Pembatasan ini tidak bermaksud mengeksklusi dan menyederhanakan kekhususan atau kekhasan trauma kolektif, namun penulis berupaya mengimajinasikan pelayanan pastoral yang terbuka pada dimensi tanpa kata sebagai alternatif yang penting dalam proses pemulihan trauma individual.

\section{Pelayanan Tanpa Kata: Tubuh yang Mengingat}

Babette Rothschild dalam bukunya yang berjudul The Body Remembers mengatakan ada gap antara tubuh-pikiran, psikoterapi tradisional-psikofisioterapi, dan teori-praktik ${ }^{3}$. Karena itu, ia berupaya menjembatani gap antara kedua kubu yang saling terpisah tersebut. Baginya, praktisi terapi tradisional mesti menyadari bahwa tubuh pun

\footnotetext{
${ }^{2}$ Pauline Patricia, Khotbah yang Menubuh: Kata yang Menubuh, Tubuh yang Terpecah, dan Ruang Tanpa Kata sebagai Situs Penyaksian Trauma. Tesis. (Jakarta: Sekolah Tinggi Teologi Jakarta, 2018): 17.

${ }^{3}$ Babette Rothschild, The Body Remembers: The Psychophysiology of Trauma and Trauma Treatment. (New York: W.W. Norton \& Company, 2000): xiii.
} 
memiliki andil dalam mengingat dan memulihkan trauma yang dialami oleh seseorang. Bagi penulis, gap terjadi pula dalam pelayanan pastoral.

Pelayanan pastoral adalah pelayanan bela rasa. Permasalahannya, ada saja pastor yang menjalankan tugasnya tanpa semangat tersebut. Seringkali seorang pastor secara gegabah menghadapi konseli yang mengalami trauma dengan banyak kata dan nasihatnasihat praktis. Padahal, belum tentu nasihat-nasihat itu diperlukan oleh konseli. Ada pula pastor yang tidak peka dan secara sembarangan menyentuh bagian tubuh konseli yang sensitif. Sekalipun pastor tersebut melakukannya tanpa maksud apapun, namun tanpa disadari sentuhan itu hanya memberi efek traumatis berulang bagi sang konseli yang secara khusus mengalami kekerasan fisik maupun kekerasan seksual.

Karena itu, penulis sependapat dengan Babette ketika ia mendefinisikan trauma sebagai berikut, "Trauma is a psychophysical experience, even when the traumatic event causes no direct bodily harm" ${ }^{\text {"4 }}$. Sekalipun suatu peristiwa traumatis tidak meninggalkan luka yang kasat mata bukan berarti luka itu tidak eksis atau tidak nyata. Selalu ada koneksi antara tubuh dan otak (mind). Keduanya saling terintegrasi memberi informasi apabila kita kehilangan data-data penting dalam memori. Secara umum, Babette memberi gambaran umum tentang apa itu memori sebagai berikut,

Memory has to do with the recording, storage, and recall of information perceived from the internal and external environments. All of the senses are integral to how the world is perceived. The brain processes perceptions and stores them as thoughts, emotions, images, sensations, and behavioral impulses. When these stored items are recalled, that is memory ${ }^{5}$.

Berdasarkan pengertian ini, manusia memiliki kemampuan untuk memanggil (recall) ingatan yang tersimpan dalam otak ${ }^{6}$. Bagi beberapa orang yang mengalami peristiwa traumatik, ingatan itu dimungkinkan untuk dipanggil dan dinarasikan ${ }^{7}$. Namun, untuk kasus-kasus tertent ${ }^{8}$. Babette mengatakan recalling memory memerlukan pendekatan yang berbeda. Lebih lanjut ia menjelaskan, "They may still be disturbed by intense emotions and/or bodily sensations seemingly unconected to the traumas they suffered".

\footnotetext{
${ }^{4}$ Ibid., 5 .

${ }^{5}$ Ibid., 26.

${ }^{6}$ Memori terbagi menjadi dua kategori yakni, memori jangka panjang (long-term memory) dan memori jangka pendek (short-term memory). Memori jangka panjang menampung infomasi secara permanen sedangkan memori jangka pendek hanya menampung informasi dalam jangka waktu yang singkat. Pada umumnya, peristiwa traumatik tersimpan dalam ingatan jangka panjang.

${ }^{7}$ Ibid., 15.

${ }^{8}$ Yang dimaksud adalah mereka yang mengalami Post Traumatic Stress Disorder (PTSD) dan Post Traumatic Stress (PTS).

${ }^{9}$ Ibid., 15.
} 
Karena itu, pelayanan terapi pada kasus-kasus khusus tersebut mesti mempertimbangkan pelayanan tanpa kata melainkan membiarkan tubuh yang mengingat itu bernarasi.

Tubuh memiliki kemampuan untuk mengingat. Hal ini senada dengan yang Babette katakan, "The body also remembers positive feelings. Awareness of body sensations can be a superhighway to the past, a tool for helping the client connect not only with forgotten traumatic memories but also with forgotten resource" ${ }^{\text {"10 }}$. Berdasarkan pernyataan itu, tubuh dimungkinkan menjadi sumber primer atas segala peristiwa pahit yang tak mampu diingat dan dikatakan.

Pelayanan tanpa kata atas mereka yang tak mampu mengartikulasikan pengalaman lukanya saya imajinasikan sebagai pelayanan yang melampaui verbatim. Pelayanan konseling tanpa kata tidak berarti konselor tidak diijinkan berkata maupun bersuara secara verbal. Saya membayangkan pelayanan tersebut melibatkan tubuh yang mengingat peristiwa luka berkata dan berbahasa dengan caranya sendiri. Saya mengimajinasikan tubuh yang memiliki kapasitas untuk memulihkan luka dilibatkan secara aktif dalam konseling. Hal ini hanya mungkin terjadi apabila konselor menyadari fungsinya sebagai pendamping pastoral.

Sayangnya, tidak banyak teolog-teolog pastoral peka terhadap hal ini. Aart Van Beek dalam bukunya yang berjudul Pendampingan Pastoral sedikit menyinggung fungsi pendamping pastoral yang menyembuhkan. Ia mengatakan,

Penting sekali kita menyadari bahwa emosi/ perasaan yang tertekan dan tidak terungkapkan melalui kata-kata atau ungkapan perasaan (menangis, dll) kemungkinan akan disalurkan melalui disfungsi tubuh kita. Ketika kita cemas, takut, gelisah, hal itu sering berakibat pada tubuh, misalnya rasa mual, pusing, sakit perut, dada sesak, dan sebagainya. Pada saat ini, hal yang dianggap dapat menolong adalah bagaimana pendamping melalui pendekatannya mengajak penderita untuk mengungkapkan perasaan batinnya yang tertekan. ${ }^{11}$

Bagi saya, Aart terlalu dini mengatakan pendamping pastoral harus melakukan pendekatan agar penderita bersedia mengungkapkan perasaan batinnya yang tertekan. Sarannya nampak tergesa-gesa dan seolah tidak mempertimbangkan posisi sulit konseli yang terluka. Sekalipun suara merupakan elemen penting dalam pemulihan, tetapi pastor harus memberi ruang bagi penderita tanpa mendesaknya mengungkapkan apa yang belum siap ia katakan. Pelayanan pastoral mesti terintegrasi antara kata dan tubuh.

\footnotetext{
${ }^{10}$ Ibid., 118.

${ }^{11}$ Aart Van Beek, Pendampingan Pastoral. (Jakarta: BPK Gunung Mulia, 2007): 14-15.
} 


\section{Aesthetic Therapeutic sebagai Alternatif: Pelayanan Pastoral yang Terintegrasi}

Alkitab mencatat berbagai kisah pemulihan atau mukjizat yang dilakukan oleh Yesus. Sekalipun kisah tersebut terbatas pada mukjizat kesembuhan badaniah tetapi, substansi pemulihan itu tidak hanya menyangkut kesembuhan yang tampak oleh mata melainkan perubahan paradigma mukjizat yang tak mesti menyembuhkan segala penyakit (read: luka) yang kelihatan. Peristiwa kesembuhan tidak melulu bersifat jasmaniah. Proses pemulihan yang dilakukan oleh Yesus pun tidak melulu menggunakan banyak kata.

Injil Matius 8:14-17 mencatat kisah pemulihan Yesus yang berdimensi tanpa kata. Melihat ibu mertua Petrus yang terbaring sakit karena demam, Sang Pemulih itu hanya memegang tangan perempuan tersebut tanpa mengucapkan suatu kata apapun (ay. 15). Bagi penulis, seorang pastor harus jeli membaca kisah ini. Sebab, sentuhan yang dilakukan oleh Yesus sangat erat hubungannya dengan proses kesembuhan penyakit badaniah. Tentu saja tidak semua sentuhan dapat diterima dan dipakai sebagai metode pemulihan. Dalam kasus tertentu sentuhan sangat tidak disarankan.

Selanjutnya, pelayanan minim kata itu berlanjut di ayat 16 ketika menjelang malam banyak orang menghampiri dan meminta pemulihan kepada Yesus. Di sana tertulis, Yesus menyembuhkan orang-orang yang menderita sakit hanya dengan berbicara sepatah kata. Pelayanan yang Yesus lakukan merupakan pelayanan terintegrasi antara kata dan tubuh. Hanya dengan sentuhan dan sepatah kata, Ia memulihkan ibu mertua Petrus serta banyak orang yang menderita. Ia tidak menasehati dan seolah menggurui orang-orang tersebut melainkan hadir bersama dengan mereka.

Yesus paham betul apa yang harus dilakukan atas orang-orang tersebut. Ia menggunakan metode yang tepat sasaran. Idealnya, seorang pendamping pastoral harus memiliki kepekaan seperti yang Yesus lakukan. Pertanyaannya, bagaimanakah pelayanan yang tepat sasaran atas perempuan-perempuan yang mengalami kekerasan pelecehan seksual?

Adapun isu kekerasan terhadap perempuan merupakan isu yang sangat sensitif, cenderung ditutup-tutupi karena berbagai alasan dan kepentingan, termasuk oleh korbannya. Pengalaman perempuan sebagai korban kekerasan seringkali diabaikan dan sengaja didiamkan. Budaya pun turut memaksa perempuan untuk cenderung mendiamkan kasus-kasus kekerasan yang dialaminya karena dianggap lazim. Dalam sistem patriarki, perempuan diidentifikasikan dengan emosi, sensualitas, dan tubuh. Tubuh perempuan ditempatkan pada kontrol sosial yang didominasi oleh laki-laki. 
Setidaknya, seorang pendamping pastoral memahami bahwa tubuh perempuan terdistorsi karena pelecehan seksual. Di dalam tubuh yang terdistorsi itu melekat kekecewaan, perasaan bersalah, dan berdosa yang mesti dipahami sebagai bahasa luka. Dan tidak semua perempuan mampu mengartikulasikan pengalaman luka itu dengan bahasa yang tepat.

Menurut penulis, pelayanan yang terintegrasi antara kata dan tubuh secara estetisterapis dapat menjadi alternatif dalam pelayanan pastoral atas perempuan yang mengalami trauma kekerasan seksual. Septemmy Lakawa sebagaimana dikutip oleh Shelly Rambo mengatakan,

Aesthetics is not linear, she claims, and neither is the process of grief. The timeline of healing does not point forward: it is instead, a tangled process in which the central challenge is to keep one's balance in the midst of the fluctuation. It is a dancing eschatology, employed against the violence wielded by another operation of soteriological ends ${ }^{12}$.

Secara estetis-imajinatif, tubuh memiliki kemampuan untuk memulihkan dirinya. Dalam hal ini, Lakawa menawarkan tarian yang memulihkan sebagai salah satu sumber pemulihan. ${ }^{13}$ Ia memanfaatkan gerakan sesehari yang sesungguhnya berfungsi sebagai sumber dan berdimensi pemulihan. Tarian itu sendiri secara estetis merupakan penanda tubuh yang bernarasi dan tubuh yang memulihkan.

Neil Pembroke dalam bukunya yang berjudul Renewing pastoral practice: Trinitian perspectives on Pastoral Care memberi usulan menarik tentang pelayanan pastoral sebagai sebuah polifoni. Secara harfiah polifoni berasal dari bahasa Yunani-dari kata polis (banyak) dan foni (suara). Menurut Kamus Besar Bahasa Indonesia, polifoni berarti gaya komposisi musik yang menggabungkan dua suara atau lebih. Dalam hal ini, Neil Pembroke memakai gagasan David Cunningham tentang polifoni sebagai salah satu ciri-ciri sifat Trinitas. Ia mengatakan, "In relation to the triune God, polyphony refers to the way in which simultaneous difference exists as a homogeneous unity "14. Berdasarkan gagasan Cunningham tersebut, Pembroke berusaha mengkonstruksi sejauh mana polifoni

${ }^{12}$ Shelly Rambo, Salvation in the after-living: reflections on salvation with Joshua Ralston and Sharon Betcher. Comparing Faithfully: Insights for Systematic Theological Reflection, (2016): 312.

${ }^{13}$ Dalam tulisannya untuk Viveka STFT Jakarta tanggal 21 Februari 2017 Lakawa mengatakan, pendekatan koreografis ini bertumpu pada hubungan antara 3 dimensi, yaitu feminis-misional-trauma. Ketiganya adalah tubuh, nafas, dan suara luka. Tarian itu terbuka terhadap luka yang senyap, para penarinya bergerak sekaligus diam, baik dengan mengikuti irama yang terdengar, maupun irama yang senyap, yang datang dari suara-luka dan pemulihan atasnya (hlm 3-4).

${ }^{14}$ Neil Pembroke, Renewing pastoral practice: Trinitian perspectives on Pastoral Care and Counseling. (USA: Ashgate Publishing Company, 2006): 21. 
secara metaforis dapat dipakai sebagai tanda kehadiran hadirat Allah Trinitas yang memelihara dan memulihkan.

Percakapan tentang Trinitas dalam kaitannya dengan pelayanan pastoral sangat menarik untuk dikaji. Apalagi karena Pembroke berusaha mengkonstruknya secara teologis-estetis. Usaha ini memperlihatkan bahwa pelayanan pastoral dapat dilakukan dengan kreatif-imajinatif. Mengingat, sebagai seorang konselor kita tidak selalu memiliki pengetahuan yang utuh tentang psikoterapi dalam visitasi pastoral yang sementara dilakukan. Selalu ada kejutan-kejutan yang terjadi di lapangan dan menurut Pembroke hal ini sangat lumrah. Selayaknya Allah Trinitas selalu memberi ruang dalam pribadi-Nya dan ciptaan, maka selalu ada kemungkinan-kemungkinan lain dalam pelayanan pastoral yang mengejutkan. Karena itu, Pembroke mengusulkan beberapa istilah yakni wisdom dan folly (kebodohan, ketotolan) untuk membahasakan jalinan nada-nada polifoni yang secara simultan dimainkan, tetapi menghasilkan karya yang baik. Kadang tidak tersturktur, kadang mendalam, dan karena itu kearifan sang konselor untuk me-manage the space itu sangat diperlukan ${ }^{15}$. Namun, tidak menutup kemungkinan kebodohan yang dilakukan oleh konselor memungkinkan terjadinya proses pemulihan atau pastoral yang tepat.

Secara khusus Pembroke memakai ide Colin Gunton tentang personal space dalam refleksi trinitariannya ${ }^{16}$. Istilah personal space dipakai bukan tanpa alasan. Lebih lanjut, Pembroke menjelaskannya sebagai berikut,

The persons in the Godhead need space to be (there is differentiation in the one God), and so do the humans created in the divine image. When there is a compression of the interpersonal space there is a failure to respect otherness. Too much space, on the other hand, means that there is no possibility of communion (the problem of individualism) ${ }^{17}$.

Ruang antara person itu menandakan adanya jarak (nearness dan distance sekaligus) dalam satu komuni yang utuh. Apabila dikaitkan dengan pelayanan pastoral, maka kearifan ini mengajarkan konselor untuk tetap memiliki ruang antara dirinya dengan kliennya. Secara khusus, polifoni dipakai sebagai alternatif untuk menggambarkan adanya ruang personal antara Allah Trinitas dengan praktik pelayanan pastoral yang menyiratkan kesatuan sekaligus perbedaan.

Dalam musik polifoni tidak ada nada-nada yang dimainkan secara dominan. Semua nada dimainkan dengan penuh imajinatif dan menghasilkan permainan musik yang indah.

\footnotetext{
15 Ibid., 21.

16 Ibid., 21.

${ }^{17}$ Ibid., 21.
} 
Demikian pula halnya Allah Trinitaris yang tidak memerankan peran-Nya secara dominan. Dalam satu komuni Ia mempertahankan imanensi dan distansi. Selain itu, Cunningham mengatakan bahwa aksi dan hasrat Allah selalu dimainkan secara simultan seperti alunan musik yang memainkan banyak notasi sekaligus. Ia mencontohkan kisah hidup Yesus yang secara dialektis menampilkan aksi dan hasrat-Nya secara bersamaan,

At times he is supremely active, narrating the nature of God's Reign, embodying that Reign through exorcisms and healings. At other times he is clearly acted upon; he is given birth, raised in a Jewish home, questioned by the religious leaders of the day, driven away by angry crowds, and-most obviously - arrested, interrogated, tried, stripped, mocked, and crucified. That is the incarnate God can be 'acted upon' by human beings in this way is a testimony to the polyphony of action and passion in $\mathrm{God}^{18}$.

Kisah hidup Yesus merupakan polifoni aksi dan hasrat Allah atas ciptaan yang dimainkan secara simultan. Merujuk Joas Adiprasetya yang mengatakan, Yesus adalah Ruang Diantara (Sang Sela, In Between) yang mempertemukan Allah dan ciptaan maka bagi penulis penjelasan Pembroke ini nampak sangat selaras. Dengan berbagai cara, Ia berupaya mempertemukan keberjarakan manusia dengan Allah. Namun, kemanusiaan-Nya tidak dapat dinafikan ketika Ia menegur dengan keras, Ia marah, dsb. Artinya-dalam kaitannya dengan polifoni-secara selaras (melalui Yesus) nampaklah wujud aksi dan hasrat Allah atas ciptaan.

Sifat Allah yang digambarkan oleh Pembroke ini menampilkan keselarasan dalam tindakan pastoral. Lebih lanjut Pembroke mengatakan, "The caregiver needs an interpersonal style in which contrastive qualities are held together in a homogeneous manner" ${ }^{19}$. Artinya, seorang konselor harus memiliki kemampuan menjalin relasi interpersonal sekalipun dalam keterbatasannya. Pasalnya, banyak sekali seorang konselor memakai bingkai teologis dan pastoralnya yang sophisticated tanpa mempertimbangkan konteks sang konseli. Dengan demikian, baik usulan Septemmy Lakawa dan Pembroke menegaskan kembali bahwa konselor perlu melakukan pelayanan yang terintegrasi dengan membiarkan kerapuhan dan ruang persona secara terluka sebagai bagian dari pekerjaan Allah membasuh trauma yang menganga dengan cara yang kreatif-imajinatif.

\footnotetext{
18 Ibid.

${ }^{19}$ Ibid., 23.
} 


\section{Kesimpulan}

Secara praktis, pelayanan/ pendampingan pastoral yang terintegrasi membutuhkan kreativitas atau imajinasi sang konselor untuk memanfaatkan sumber-sumber sesehari sebagai alternatif pemulihan. Hanya saja, penulis menyadari bahwa tidak semua pastor memiliki akses untuk melakukan pelayanan pastoral yang tidak lazim dilakukan itu. Namun, bukan berarti pelayanan terintegrasi ini tidak dapat dilakukan.

Sudah saatnya seorang pastor beralih dari kebiasaan yang dilakukannya. Tidak selamanya pengalaman penderitaan itu diutarakan dengan bahasa yang sistematis. Secara khusus bahasa penderitaan yang khas dialami oleh perempuan dengan pengalaman kekerasan seksual, pendampingan pastoral tidak boleh terkesan mendesak ia yang terluka untuk mengisahkan pengalamannya. Konselor harus beralih dari pelayanan banyak kata menjadi pelayanan minim kata. Pelayanan yang terbuka pada kegagalan maupun pelayanan yang tepat sasaran pada konteks tertentu.

Sebagaimana Cathy Caruth katakan, "suara" dan "luka" merupakan situs yang tidak terselami tetapi menuntut didengar dan dipahami, sebagai suara yang asing karena ia keluar dari ruang yang terluka. Maka, tubuh perempuan yang menampung situs kekerasan, trauma, tetapi juga situs pemulihan itu menyuarakan lukanya dengan tarian. Karena itu, penulis mengimajinasikan pelayanan pastoral yang aesthetic-therapeutic dimana keindahan dapat dipakai sebagai alternatif untuk pemulihan. Pelayanan yang turut mengundang Allah menari diiringi lantunan polifoni dalam upaya pemulihan. Pelayanan pastoral tidak hanya sebatas soal kata dan suara tetapi, ada ruang terbuka untuk membiarkan tubuh yang mengingat itu memulihkan dirinya secara indah.

\section{Kepustakaan}

Levine, Peter A. In an Unspoken Voice: How the Body Releases Trauma and Restores Goodness. California: North Atlantic Books, 2010.

Patricia, Pauline. Khotbah yang Menubuh: Kata yang Menubuh, Tubuh yang Terpecah, dan Ruang Tanpa Kata sebagai Situs Penyaksian Trauma. Tesis. Sekolah Tinggi Teologi Jakarta, 2018.

Pembroke, Neil. Renewing pastoral practice: Trinitian perspectives on Pastoral Care and Counseling. USA: Ashgate Publishing Company, 2006.

Rambo, Shelly. Salvation in the after-living: reflections on salvation with Joshua Ralston and Sharon Betcher. Comparing Faithfully: Insights for Systematic Theological Reflection, 2016.

Rothschild, Babette. The Body Remembers: The Psychophysiology of Trauma and Trauma Treatment. New York: W.W. Norton \& Company, 2000. 
Van Beek, Aart. Pendampingan Pastoral. Jakarta: BPK Gunung Mulia, 2007. 